\title{
SOEP
}

SOEPpapers

on Multidisciplinary Panel Data Research

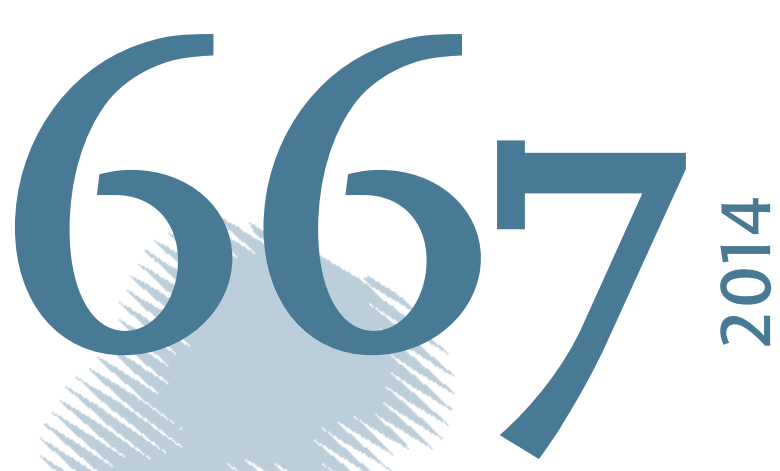

\section{On the Stability of Preferences: Repercussions of Entrepreneurship on Risk Attitudes}

Matthias Brachert and Walter Hyll 


\section{SOEPpapers on Multidisciplinary Panel Data Research}

at DIW Berlin

This series presents research findings based either directly on data from the German SocioEconomic Panel Study (SOEP) or using SOEP data as part of an internationally comparable data set (e.g. CNEF, ECHP, LIS, LWS, CHER/PACO). SOEP is a truly multidisciplinary household panel study covering a wide range of social and behavioral sciences: economics, sociology, psychology, survey methodology, econometrics and applied statistics, educational science, political science, public health, behavioral genetics, demography, geography, and sport science.

The decision to publish a submission in SOEPpapers is made by a board of editors chosen by the DIW Berlin to represent the wide range of disciplines covered by SOEP. There is no external referee process and papers are either accepted or rejected without revision. Papers appear in this series as works in progress and may also appear elsewhere. They often represent preliminary studies and are circulated to encourage discussion. Citation of such a paper should account for its provisional character. A revised version may be requested from the author directly.

Any opinions expressed in this series are those of the author(s) and not those of DIW Berlin. Research disseminated by DIW Berlin may include views on public policy issues, but the institute itself takes no institutional policy positions.

The SOEPpapers are available at

http://www.diw.de/soeppapers

\section{Editors:}

Jürgen Schupp (Sociology)

Gert G. Wagner (Social Sciences, Vice Dean DIW Graduate Center)

Conchita D'Ambrosio (Public Economics)

Denis Gerstorf (Psychology, DIW Research Director)

Elke Holst (Gender Studies, DIW Research Director)

Frauke Kreuter (Survey Methodology, DIW Research Professor)

Martin Kroh (Political Science and Survey Methodology)

Frieder R. Lang (Psychology, DIW Research Professor)

Henning Lohmann (Sociology, DIW Research Professor)

Jörg-Peter Schräpler (Survey Methodology, DIW Research Professor)

Thomas Siedler (Empirical Economics)

C. Katharina Spieß (Empirical Economics and Educational Science)

ISSN: 1864-6689 (online)

German Socio-Economic Panel Study (SOEP)

DIW Berlin

Mohrenstrasse 58

10117 Berlin, Germany

Contact: Uta Rahmann | soeppapers@diw.de 


\title{
On the Stability of Preferences: \\ Repercussions of Entrepreneurship on Risk Attitudes
}

\author{
by \\ Matthias Brachert \\ Halle Institute for Economic Research \\ and \\ Walter Hyll* \\ Halle Institute for Economic Research
}

*Corresponding author

Mailing Address: Walter Hyll

Halle Institute for Economic Research

Kleine Maerkerstrasse 8

D-06108 Halle

Germany

E-Mail Address: walter.hyll@iwh-halle.de

Phone: $\quad+493457753850$

Fax: $\quad+493457753779$ 


\title{
On the Stability of Preferences:
}

\section{Repercussions of Entrepreneurship on Risk Attitudes}

\begin{abstract}
The majority of empirical studies make use of the assumption of stable preferences in searching for a relationship between risk attitude and the decision to become and stay an entrepreneur. Yet empirical evidence on this relationship is limited. In this paper, we show that entry into entrepreneurship itself plays a decisive role in shaping risk preferences. We find that becoming self-employed is indeed associated with a relative increase in risk attitudes, an increase that is quantitatively large and significant even after controlling for individual characteristics, different employment status, and duration of entrepreneurship. The findings suggest that studies assuming that risk attitudes are stable over time suffer from reverse causality; risk attitudes do not remain stable over time, and individual preferences change endogenously.
\end{abstract}

Keywords: Endogenous preferences, Risk attitudes, Entrepreneurship, German SocioEconomic Panel

JEL classification: D03, D81, M13 


\section{INTRODUCTION}

Entrepreneurship is crucial for the efficient functioning of markets and the prevention of excess profits (Audretsch, Keilbach \& Lehmann, 2006). Entrepreneurs are considered engines for (regional) structural change and economic growth (Audretsch \& Fritsch, 1994). Therefore, it is important to understand the determinants of individual decisions to become an entrepreneur or to remain regularly employed. In this context, risk attitudes are a decisive factor in explaining individual decisions to become an entrepreneur (Barsky et al., 1997; Cramer et al., 2002; Fairlie, 2002; Caliendo, Fossen \& Kritikos, 2009, 2014). Although it is intuitively appealing to assume that entrepreneurs are willing to take significant risks, most empirical studies use this argument in searching for a relationship between risk attitude and the decision to become and stay an entrepreneur. This argument, however, comes at a cost of treating individual risk attitudes as stable over time and assuming that these attitudes are not affected by entry into entrepreneurship (Barsky et al., 1997; Caliendo, Fossen \& Kritikos, 2009, 2010). ${ }^{1}$ To our knowledge, the validity of these assumptions has not been tested so far. Consequently, this paper aims to answer the question whether risk attitudes indeed remain stable over time or whether they are subject to changes caused by entry into entrepreneurship. $^{2}$

Entrepreneurs' risk attitudes may be related to endogenous adaptation for several reasons. ${ }^{3}$ First, becoming an entrepreneur means confronting risky decisions new to the individual (Caliendo, Fossen \& Kritikos, 2009). Second, making risky decisions implies dealing with uncertainty and may contribute to learning in the business context (Das \& Teng, 1997; Janney \& Dess, 2006). Learning by doing is a pervasive form of personal development which can be applied to preferences as well as skills (Bowles, 1998). With respect to entrepreneurship, this may include the accumulation of entrepreneurship-specific human capital and an increasing confidence in own skills (Westhead \& Wright, 1998; Ucbasaran, Wright \& Westhead, 2003, 2008; Amaral, Baptista \& Lima, 2011). ${ }^{4}$ This learning might be of special relevance in the early stage of entrepreneurship where people learn from experiences of acting in and responses from the market and thus contribute to potential changes in individual risk attitudes

\footnotetext{
${ }^{1}$ See also Jaeger et al. (2010) for a similar assumption in the context of risk attitudes and migration.

${ }^{2}$ This paper focuses on individuals who became entrepreneurs. When using the notion of entrepreneur, as well as entrepreneurship, we mean people who experienced a recent transition to entrepreneurship. We use this definition throughout the paper.

${ }^{3}$ See Bowles (1998) for a more general discussion on endogenous preferences.

${ }^{4}$ Recent discussions in the entrepreneurship literature also highlight the importance of personality traits as potentials means to explain employment status (Zhao \& Seibert, 2006; Borghans et al., 2008). However, even after controlling for the effects of personality traits, Caliendo, Fossen and Kritikos (2014) find that information about risk attitudes has an influence on entrepreneurial activity.
} 
through self-attribution (Lane, 1991; Bowles, 1998; Politis, 2005; van Gelderen, van der Sluis \& Jansen, 2005).

Thus, it is not obvious whether risk attitudes affect entrepreneurial activity, or vice versa. On the former link, empirical literature presents unidirectional and inconclusive findings. While Cramer et al. (2002) find support for a positive relationship between risk tolerance and entrepreneurial entry, Barsky et al. (1997) find no statistically significant effect of risk tolerance on selection into self-employment. Caliendo, Fossen and Kritikos (2009) show that individuals with a lower risk aversion are more likely to become self-employed. Hartog, Ferrer-i Carbonell and Jonker (2002) present evidence that successful entrepreneurs are less risk averse than regularly employed people. Fairlie (2002) provides indirect evidence on the hypotheses that risk seeking individuals more likely become self-employed in showing that (former) drug dealing has a large and significant effect on the probability of self-employment. Ahn (2010) uses longitudinal data on risk tolerance to control for measurement error. His results indicate that relative risk tolerance has a positive and statistically significant effect on the probability of entering self-employment. Sarasvathy, Menon and Kuechle (2013), however, argue that entrepreneurs fall along the entire risk preference spectrum, casting serious doubts on the supra-normal risk attitude assumption (see also Brockhaus, 1980; Sarasvathy, Simon \& Lave, 1998). Nevertheless, it should be noted, that most studies measure individual risk attitudes by single responses when individuals already are entrepreneurs.

What is missing in this discussion is the situation in which risk attitudes may change in the face of entrepreneurship as a result of entrepreneurial learning (Block, Sandner \& Spiegel, 2013). As mentioned previously, current empirical approaches do not go beyond comparing risk attitudes of existing entrepreneurs with different categories of employed or unemployed people. Only Caliendo, Fossen and Kritikos (2009) examine whether the decision to start a business is influenced by risk attitudes at the time the decision is made. Regardless, no study has analyzed the relationship between the decision to become an entrepreneur and changes in individual risk attitudes. This paper aims to fill this gap. We make use of data from different waves of an experimentally validated questionnaire, the German Socio-Economic Panel (SOEP). The SOEP contains information about individuals' willingness to take risks in general and in specific contexts, including occupation, which constitutes a relevant domain for employment decisions (Caliendo, Fossen \& Kritikos, 2010). We apply a difference-indifference approach and examine whether individuals differ in their willingness to take occupational risks after having experienced self-employment, an economic action related to 
risk-seeking individuals. We test whether individuals who become entrepreneurs express a different trend in risk attitudes than individuals who do not enter entrepreneurship.

We find that entry into entrepreneurship is indeed associated with a relative increase in risk attitudes, an increase that is quantitatively large and significant even after controlling for individual characteristics, different employment status, and duration of entrepreneurship. We further show that these changes in risk attitudes dominate the effect of initial differences in individual risk levels. The findings suggest that studies assuming that risk attitudes are stable over time suffer from reverse causality; risk attitudes do not remain stable over time, and individual preferences change endogenously.

\section{DATA}

The SOEP, the underlying data set, is a representative survey of the German population and was initiated in 1984. It contains a large variety of longitudinal information on approximately 22,000 individuals. ${ }^{5}$ We have information about the individual willingness to take risks for two periods. Our primary measure of risk attitude was added to the SOEP in the 2004 wave and was collected for a second wave in 2009. Therefore, we make use of the waves from 2004 to 2009, and for our robustness analysis, we also consider the waves 2003, 2010, 2011, and 2012.

We focus on time trends in occupational risk attitude, which is considered most relevant in the context of entrepreneurship or self-employment (see also Caliendo, Fossen and Kritikos 2009). ${ }^{6}$ The behavioral relevance of the risk measure used herein has been validated in a large-scale experiment. Using a representative sub-sample of 450 participants, Dohmen et al. (2011) show that the SOEP measures of risk attitudes have good predictive power of risktaking attitudes involving self-employment. In line with Caliendo, Fossen and Kritikos (2009) and Dohmen et al. (2012), we thus assume that using SOEP data provides behaviorally valid information on individual risk attitudes.

To identify the effect of entrepreneurship on risk attitudes, we first use risk information of individuals (riskocc04) at a time they were not self-employed (future entrepreneurs given the

\footnotetext{
${ }^{5}$ For more detailed information about the SOEP, see Wagner, Burkhauser and Behringer (1993) and Wagner, Frick and Jürgen Schupp (2007). Further information is available at http://www.diw.de/en/diw_02.c.221178.en/about_soep.html (accessed February 3, 2014).

${ }^{6}$ The exact question used to derive information about individual risk attitude is as follows: "People can behave differently in different situations. How would you rate your willingness to take risks in your occupation?” People respond to an 11-point scale, where values of 0 indicate high risk aversion and values of 10 indicate full willingness to take risks.
} 
year 2004). Second, we measure risk at an additional point in time (2009) after some of the individuals became self-employed (riskocc09). Thus, we identify entry into entrepreneurship if an individual was not self-employed in 2004 but was in one of the subsequent years.

We rely on two measures of self-employment as proxies for entrepreneurship. The first measure refers to occupational status: individuals are classified as entrepreneurs if they experienced a change in their occupational status to self-employment as their main position (selfemp). Second, we rely on whether an individual experienced changes in receiving income from self-employment. That is, individuals are classified as entrepreneurs if they began receiving an income from self-employment in one of the years after 2004 (inc_selfemp). We add both proxies, inc_selfemp and selfemp, to the empirical analysis as dummy variables, with the value of 1 if individuals experienced the respective transitions.

We restrict the sample to individuals between 17 years of age in 2004 and 65 years of age in 2009, who were either employed or unemployed in $2004 .^{7}$ This leaves us with a balanced panel data set containing information on 7353 individuals, 324 of whom decided to start a business during the 2005 and 2009 periods, with entrepreneurship based on the income measure. If entrepreneurship is based on self-employment as a main activity, we are left with 267 individuals who became entrepreneurs.

\footnotetext{
${ }^{7}$ This means that we exclude non-employed individuals, individuals in vocational training, individuals doing an internship, and individuals in military or civil service from the analysis. We also exclude individuals with missing information on any of the variables used to perform the analysis. Regarding the choice of occupational profiles, robustness checks show that the exclusion of certain groups does not affect the significance and direction of the results.
} 


\section{RISK ATTITUDES OF SELF-EMPLOYED AND NON-SELF-EMPLOYED}

\section{FIGURE 1}

Changes in risk attitudes from 2004 to 2009 for entrepreneurs and non-entrepreneurs
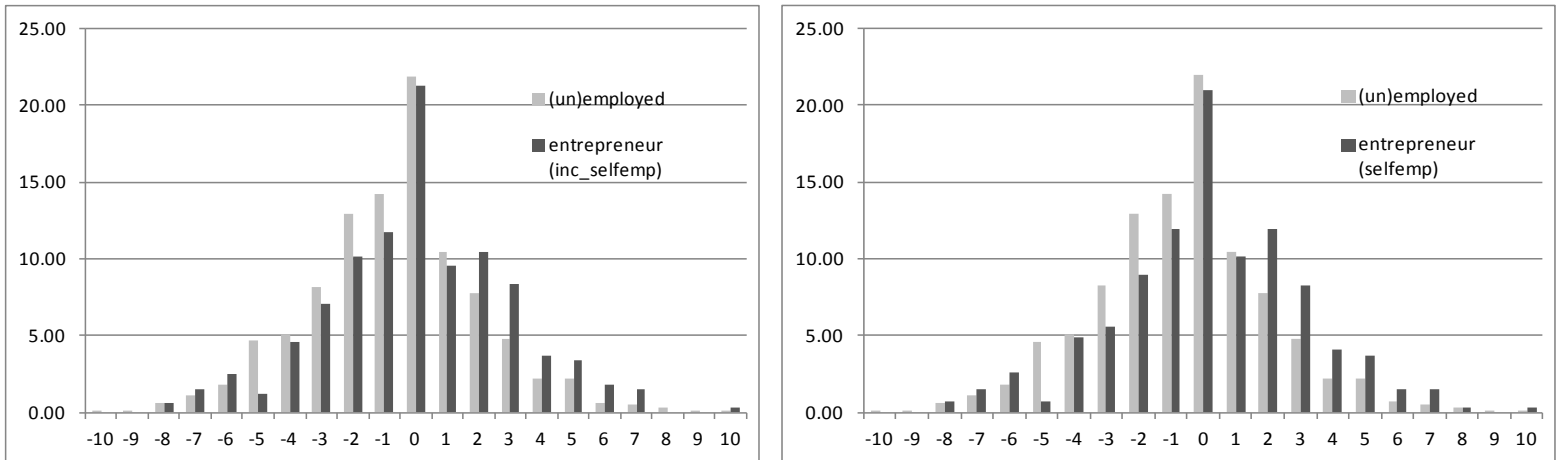

Source: Authors own illustration from Socio-Economic Panel (SOEP), data for years 1984-2010, version 27, SOEP, 2011, doi:10.5684/soep.v27.

Figure 1 shows the distributions of the change rates in the willingness to take occupational risks (riskocc0409) for entrepreneurs and individuals with no transition between 2005 and 2009. We derive time trends in individual risk attitudes by calculating the difference in risk values from 2009 and 2004 (riskocc0409 = riskocc09 - riskocc04). Because both riskocc04 and riskocc09 are measured on 11-point scales, the variable riskocc0409 can reach values from -10 to +10 . The left-hand side of figure 1 measures entrepreneurship with the income definition (inc_selfemp). On the right-hand side, entrepreneurship refers to changes to selfemployment as the main occupational status (selfemp). As both figures show, there are substantial changes in individual risk attitudes in occupation over time, regardless of the transition towards entrepreneurship. Only roughly $22 \%$ of non-entrepreneurs and $21 \%$ of nascent entrepreneurs show stable patterns in the willingness to take occupational risks. A more detailed comparison of the two distributions reveals differences between both nascent entrepreneurs and non-entrepreneurs. While both distributions are centered on zero, the distribution for entrepreneurs in both figures has more weight on the right-hand side. In contrast, the distribution of non-entrepreneurs has more weight on the left-hand side (see also table 1). Furthermore, a greater proportion of self-employed than non-self-employed people experience an increase in the willingness to take occupational risks, while a greater proportion of non-self-employed than self-employed people exhibit a decrease in risk preference. 
TABLE 1

Risk attitudes from 2004 and 2009 for non-entrepreneurs, (future) entrepreneurs, and 2004 entrepreneurs

\begin{tabular}{|c|c|c|c|c|c|}
\hline & \multirow{2}{*}{$\begin{array}{l}\text { Non-entrepreneurs: } \\
\text { employed and } \\
\text { unemployed }\end{array}$} & \multicolumn{2}{|c|}{ (future) Entrepreneurs } & \multicolumn{2}{|c|}{$\begin{array}{l}\text { Entrepreneurs already in } \\
2004\end{array}$} \\
\hline & & inc_selfemp & selfemp & inc_selfemp & selfemp \\
\hline Average risk attitude 2004 & 3.913 & 4.876 & 4.835 & 5.27 & 5.21 \\
\hline Average risk attitude 2009 & 3.284 & 4.913 & 5.014 & 4.672 & 4.612 \\
\hline $\begin{array}{l}\text { Average change in risk } \\
\text { attitude }\end{array}$ & -0.629 & 0.037 & 0.179 & -0.597 & -0.598 \\
\hline$\%$ change in risk $<0$ & 48.94 & 39.51 & 37.08 & 50.74 & 51.30 \\
\hline$\%$ change in risk $>0$ & 29.14 & 39.20 & 41.95 & 31.99 & 31.13 \\
\hline $\mathrm{N}$ & 7029 & 324 & 267 & 544 & 575 \\
\hline
\end{tabular}

Table 1 provides additional results of some basic descriptive statistics. We depict for (future) entrepreneurs and non-entrepreneurs the average risk index for the years 2004 (riskocc04) and 2009 (riskocc09), as well as the change in the risk index (riskocc0409). The yearly risk indices for 2004 and 2009 are substantially larger for (future) entrepreneurs, which is in line with Caliendo, Fossen and Kritikos's (2009, 2014) studies. However, while (future) entrepreneurs, on average, experience an increase in their risk index from 0.04 to 0.18 , nonentrepreneurs behave differently and show risk attitudes that decrease by 0.60 points. For comparison only, columns 5 and 6 of table 1 show the corresponding values for individuals who had already been self-employed in 2004. Though their average risk indices for the years 2004 and 2009 are higher than for non-entrepreneurs, these individuals experience a decrease in their risk index similar to non-entrepreneurs. 
TABLE 2

Average risk changes for entrepreneurs (inc_selfemp) and non-entrepreneurs

\begin{tabular}{|c|c|c|c|c|c|c|c|}
\hline & \multicolumn{2}{|c|}{ Average risk change } & \multicolumn{2}{|c|}{$\mathrm{N}$} & \multirow[b]{2}{*}{$\begin{array}{c}\text { Share } \\
\text { selfemp }\end{array}$} & \multicolumn{2}{|c|}{ Share within } \\
\hline & $\begin{array}{l}\text { Non- } \\
\text { Entrpr. }\end{array}$ & Entrpr. & $\begin{array}{c}\text { Non- } \\
\text { Entrpr. }\end{array}$ & Entrpr. & & $\begin{array}{c}\text { Non- } \\
\text { Entrpr. }\end{array}$ & Entrpr. \\
\hline All & -0.629 & 0.037 & 7029 & 324 & 4.41 & & \\
\hline \multicolumn{8}{|l|}{ Sex } \\
\hline Male & -0.619 & -0.238 & 3546 & 193 & 5.16 & 50.45 & 59.57 \\
\hline Female & -0.640 & 0.443 & 3483 & 131 & 3.62 & 49.55 & 40.43 \\
\hline \multicolumn{8}{|l|}{ Age } \\
\hline $17-25$ & -0.171 & 0.043 & 480 & 23 & 4.57 & 6.83 & 7.10 \\
\hline $26-35$ & -0.413 & 0.354 & 1507 & 99 & 6.16 & 21.44 & 30.56 \\
\hline $36-45$ & -0.641 & 0.116 & 2393 & 112 & 4.47 & 34.04 & 34.57 \\
\hline $46-60$ & -0.825 & -0.411 & 2649 & 90 & 3.29 & 37.69 & 27.78 \\
\hline \multicolumn{8}{|l|}{ ISCED } \\
\hline $0-2$ & -0.449 & 0.087 & 809 & 23 & 2.76 & 11.64 & 7.32 \\
\hline $3-4$ & -0.657 & 0.226 & 3958 & 159 & 3.86 & 56.97 & 50.64 \\
\hline $5-6$ & -0.659 & -0.227 & 2181 & 132 & 5.71 & 31.39 & 42.04 \\
\hline \multicolumn{8}{|l|}{ Work exp. } \\
\hline 0 & -0.070 & 0.172 & 243 & 29 & 10.66 & 3.46 & 8.95 \\
\hline $0.1-5$ & -0.424 & 0.140 & 1175 & 57 & 4.63 & 16.72 & 17.59 \\
\hline 5.1-10 & -0.584 & 0.633 & 1167 & 79 & 6.34 & 16.61 & 24.38 \\
\hline$>10$ & -0.725 & -0.321 & 4441 & 159 & 3.46 & 63.21 & 49.07 \\
\hline \multicolumn{8}{|c|}{ Unemp exp. } \\
\hline 0 & -0.570 & 0.168 & 4256 & 184 & 4.14 & 60.58 & 56.79 \\
\hline $0.1-1$ & -0.682 & -0.431 & 1445 & 72 & 4.75 & 20.57 & 22.22 \\
\hline $1.1-2$ & -0.639 & -0.194 & 485 & 31 & 6.01 & 6.90 & 9.57 \\
\hline$>2$ & -0.824 & 0.486 & 840 & 37 & 4.22 & 11.96 & 11.42 \\
\hline \multicolumn{8}{|c|}{ Job duration } \\
\hline $0-5$ & -0.486 & -0.051 & 2320 & 157 & 6.34 & 36.73 & 58.15 \\
\hline $6-15$ & -0.642 & 0.175 & 2336 & 80 & 3.31 & 36.99 & 29.63 \\
\hline$>15$ & -0.719 & -0.242 & 1660 & 33 & 1.95 & 26.28 & 12.22 \\
\hline \multicolumn{8}{|l|}{ Married } \\
\hline No & -0.620 & -0.073 & 2556 & 137 & 5.09 & 36.36 & 42.28 \\
\hline Yes & -0.635 & 0.118 & 4473 & 187 & 4.01 & 63.64 & 57.72 \\
\hline \multicolumn{8}{|l|}{ Kids } \\
\hline 0 & -0.690 & -0.085 & 4305 & 177 & 3.95 & 61.25 & 54.63 \\
\hline 1 & -0.607 & -0.286 & 1414 & 77 & 5.16 & 20.12 & 23.77 \\
\hline$\geq 2$ & -0.455 & 0.700 & 1310 & 70 & 5.07 & 18.64 & 21.60 \\
\hline \multicolumn{8}{|l|}{ Living } \\
\hline East & -0.772 & 0.021 & 1850 & 94 & 4.84 & 26.32 & 29.01 \\
\hline West & -0.578 & 0.043 & 5179 & 230 & 4.25 & 73.68 & 70.99 \\
\hline \multicolumn{8}{|l|}{ Origin } \\
\hline Abroad & -0.415 & 0.375 & 458 & 16 & 3.38 & 6.52 & 4.94 \\
\hline Germany & -0.644 & 0.019 & 6571 & 308 & 4.48 & 93.48 & 95.06 \\
\hline \multicolumn{8}{|l|}{ Disable } \\
\hline No & -0.613 & 0.055 & 6568 & 307 & 4.47 & 93.63 & 94.75 \\
\hline Yes & -0.877 & -0.294 & 447 & 17 & 3.66 & 6.37 & 5.25 \\
\hline \multicolumn{8}{|c|}{ Inc. Finance } \\
\hline No & -0.614 & 0.234 & 5306 & 214 & 3.88 & 75.49 & 66.05 \\
\hline Yes & -0.676 & -0.345 & 1723 & 110 & 6.00 & 24.51 & 33.95 \\
\hline \multicolumn{8}{|l|}{ Height } \\
\hline $0-180$ & -0.647 & 0.132 & 5727 & 243 & 4.07 & 81.62 & 75.00 \\
\hline$\geq 181$ & -0.556 & -0.247 & 1290 & 81 & 5.91 & 18.38 & 25.00 \\
\hline \multicolumn{8}{|c|}{ Father entrep. } \\
\hline No & -0.649 & 0.007 & 6440 & 276 & 4.11 & 91.62 & 85.19 \\
\hline Yes & -0.418 & 0.208 & 589 & 48 & 7.54 & 8.38 & 14.81 \\
\hline
\end{tabular}

Source: Authors own calculation from Socio-Economic Panel (SOEP), data for years 1984-2010, version 27, SOEP, 2011, doi:10.5684/soep.v27.

Notes: (Control) variables refer to the year 2004. A detailed description of the variables appears in the appendix. 
In table 2, we present for entrepreneurs (based on the income definition) and nonentrepreneurs the changes in the risk index from 2004 to 2009, sub-divided by a variety of socio-economic characteristics. These variables later serve as controls in the empirical framework to identify the effect of entrepreneurship on changes in the individual willingness to take occupational risks. In general, non-entrepreneurs are characterized by a reduction in their willingness to take risks in all sub-categories. In contrast, entrepreneurs experience an increase in their risk index in the vast majority of sub-categories (24 of 37). In the cases that show negative changes in risk attitudes, this decrease is still comparatively smaller than those of the non-entrepreneurs.

\section{ENTREPRENEURSHIP AS DETERMINANT OF CHANGES IN INDIVIDUAL RISK ATTITUDES}

The results of the descriptive analysis show that the personal willingness to take occupational risks changes over time and that it changes differently for people who become entrepreneurs than for non-entrepreneurs. In search of a causal effect of entry into entrepreneurship on risk attitudes, we apply a difference-in-difference (DiD) design (Ashenfelter, 1978; Card \& Krueger, 1994). The basic idea of a DiD identification strategy is to calculate the difference of the mean risk attitudes of entrepreneurs and non-entrepreneurs before and after the entrepreneurs started their businesses. Our empirical strategy is that only one "group" is affected by treatment, which in our case is the entry into entrepreneurship. Thus, we have information about risk attitudes on two groups, where only one group is treated in the second period, with risk attitudes measured before (in 2004) and after (in 2009) treatment for both groups.

Several assumptions must hold to infer causal mean effects for the treated group. First, the treatment must not affect risk preferences of the non-treated group, meaning that there are no relevant interactions between entrepreneurs and non-entrepreneurs (see Rubin, 1977). In our case, it is unlikely that an individual's change in willingness to take occupational risks has a direct or indirect effect on others' occupational risk attitudes. Second, individuals may anticipate becoming an entrepreneur, which involves changes in risk attitudes (affecting the pre-treatment outcome) or pre-treatment adaptation in other covariates. If this is the case, risk attitudes in 2004 might already be affected by endogeneity issues (Lechner, 2011). Our data set allows us to at least partially control for this problem. That is, we make use of a question in the SOEP wave of 2003 that asks individuals to estimate the individual probability of becoming an entrepreneur within the next two years. This question enables us to restrict the 
sample to those who did certainly not intent to become self-employed in 2004. Third, the common trend assumption is a key element of the DiD design. In our case, it implies that if entrepreneurs had not started a new business, both non-entrepreneurs and "non-entering" entrepreneurs would have experienced the same time trend in risk attitudes, conditional on the covariates (Lechner, 2011). Thus, any differences in the trend of individual willingness to take risks can be interpreted as an effect of the treatment. In section 5, we offer some evidence in favor of the common trend assumption. We make use of the SOEP waves of 2010, 2011, and 2012 to control for whether individuals who became entrepreneurs in one of these years experienced the same time trend in risk attitudes as non-entrepreneurs in the 2004-2009 period.

The underlying equation of the basic $\mathrm{DiD}$ approach can be specified as follows:

$$
Y_{i}=\beta_{0}+\beta_{1} T_{i}+\beta_{2} t_{i}+\beta_{3}\left(T_{i} \cdot t_{i}\right)+\beta_{4} X_{i}+\varepsilon_{i},
$$

where $T=0,1$ indicates whether an individual received treatment $(T=1)$ or not $(T=0)$. We observe individuals in two periods, $t=0,1$, where 0 indicates the period before treatment and 1 indicates the period after treatment. Covariates are depicted by $X$. The coefficient $\beta_{3}$ captures the true effect of the treatment.

\section{ESTIMATION RESULTS}

Before we apply DiD estimations, we directly estimate the effect of entrepreneurship on risk attitudes in 2009 when controlling for risk attitudes before the transition into self-employment in 2004. This is equivalent to estimate the effect of entrepreneurship on the change in risk attitudes after transition including the risk index 2004 as covariate. We estimate linear regression, where self-employment is measured either by inc_selfemp (columns 2 and 3) or selfemp (columns 4 and 5). Results of table 3 show that on average a transition into selfemployment is highly correlated to an increase in risk attitudes. Coefficients for female, age, and unemployment experience are all negative and highly significant. Coefficients on education, German origin, and father entrepreneurship are positive and significant. Occupational risk attitudes in 2004 itself are strongly related to risk attitudes in 2009. 
TABLE 3

OLS, sample employed and unemployed in 2004

\begin{tabular}{|c|c|c|c|c|}
\hline \multirow{3}{*}{$\begin{array}{l}\text { Dependent variable } \\
\text { inc_selfemp }\end{array}$} & \multicolumn{4}{|c|}{ Risk attitudes 2009} \\
\hline & \multicolumn{2}{|c|}{ (inc_selfemp) } & \multicolumn{2}{|c|}{ (selfemp) } \\
\hline & $\begin{array}{l}1.239 * * * \\
(0.134)\end{array}$ & $\begin{array}{l}1.104^{* * *} \\
(0.137)\end{array}$ & & \\
\hline selfemp & & & $\begin{array}{l}1.350 * * * \\
(0.151)\end{array}$ & $\begin{array}{l}1.234^{* * *} \\
(0.171)\end{array}$ \\
\hline Risk occupation 2004 & $\begin{array}{l}0.405^{* * *} \\
(0.011)\end{array}$ & $\begin{array}{l}0.357 * * * \\
(0.012)\end{array}$ & $\begin{array}{l}0.407 * * * \\
(0.011)\end{array}$ & $\begin{array}{l}0.357^{* * *} \\
(0.012)\end{array}$ \\
\hline Sex $($ female $=1)$ & & $\begin{array}{l}-0.417 * * * \\
(0.083)\end{array}$ & & $\begin{array}{l}-0.424 * * * \\
(0.083)\end{array}$ \\
\hline East & & $\begin{array}{l}0.042 \\
(0.063)\end{array}$ & & $\begin{array}{l}0.045 \\
(0.063)\end{array}$ \\
\hline Education & & $\begin{array}{l}0.136 * * * \\
(0.020)\end{array}$ & & $\begin{array}{l}0.141^{* * *} \\
(0.020)\end{array}$ \\
\hline Age & & $\begin{array}{l}-0.068 * * * \\
(0.024)\end{array}$ & & $\begin{array}{l}-0.067 * * * \\
(0.024)\end{array}$ \\
\hline Age_sq & & $\begin{array}{l}0.000 \\
(0.000)\end{array}$ & & $\begin{array}{l}0.000 \\
(0.000)\end{array}$ \\
\hline Work experience & & $\begin{array}{l}-0.002 \\
(0.004)\end{array}$ & & $\begin{array}{l}-0.001 \\
(0.004)\end{array}$ \\
\hline Unemployment experience & & $\begin{array}{l}-0.059 * * * \\
(0.015)\end{array}$ & & $\begin{array}{l}-0.059 * * * \\
(0.015)\end{array}$ \\
\hline Disable & & $\begin{array}{l}-0.168 \\
(0.117)\end{array}$ & & $\begin{array}{l}-0.166 \\
(0.117)\end{array}$ \\
\hline German & & $\begin{array}{l}0.145 \\
(0.124)\end{array}$ & & $\begin{array}{l}0.147 \\
(0.124)\end{array}$ \\
\hline Married & & $\begin{array}{l}-0.041 \\
(0.067)\end{array}$ & & $\begin{array}{l}-0.040 \\
(0.067)\end{array}$ \\
\hline Income finance & & $\begin{array}{l}0.000 \\
(0.000)\end{array}$ & & $\begin{array}{l}0.000 \\
(0.000)\end{array}$ \\
\hline Kids & & $\begin{array}{l}-0.003 \\
(0.034)\end{array}$ & & $\begin{array}{l}-0.003 \\
(0.034)\end{array}$ \\
\hline Height & & $\begin{array}{l}0.001 \\
(0.004)\end{array}$ & & $\begin{array}{l}0.001 \\
(0.004)\end{array}$ \\
\hline Father entrepreneur & & $\begin{array}{l}0.189 * * \\
(0.092)\end{array}$ & & $\begin{array}{l}0.186 * * \\
(0.092)\end{array}$ \\
\hline Constant & $\begin{array}{l}1.697^{* * * *} \\
(0.051)\end{array}$ & $\begin{array}{l}3.560 * * * \\
(0.859)\end{array}$ & $\begin{array}{l}1.698^{* * *} \\
(0.051)\end{array}$ & $\begin{array}{l}3.539 * * * \\
(0.858)\end{array}$ \\
\hline $\mathrm{N}$ & 7353 & 7119 & 7353 & 7119 \\
\hline $\mathrm{R}^{2}$ & 0.173 & 0.212 & 0.174 & 0.213 \\
\hline
\end{tabular}

Source: Authors own calculations from Socio-Economic Panel (SOEP), data for years 1984-2010, version 27, SOEP, 2011, doi:10.5684/soep.v27.

Notes: $* * *$ indicate significance at the $1 \%$ level, ${ }^{* *}$ significance at the $5 \%$ level, * significance at the $10 \%$ level. Coefficients in all columns are OLS estimates. Robust standard errors are in brackets. Covariates refer to the year 2004.

In table 4, we begin with a basic DiD design. Here, we use only individual information about risk attitudes from the years 2004 and 2009 without additional covariates. Entrepreneurs are individuals who experience a transition to entrepreneurship in at least one of the years from 2005 to 2009. When using inc_selfemp as a proxy for entrepreneurial entry, the model contains information about risk attitudes for 324 nascent entrepreneurs and 7029 remaining employed or unemployed people. When considering self_emp as a proxy, the number of 
nascent entrepreneurs decreases to 267, with 7086 remaining employed or unemployed. Table 4 reports the results.

TABLE 4

DiD approach, sample employed and unemployed in 2004, without covariates

\begin{tabular}{|c|c|c|c|c|c|c|c|}
\hline \multirow[b]{2}{*}{$\begin{array}{l}\text { Outcome } \\
\text { variable }\end{array}$} & \multicolumn{3}{|c|}{2004} & \multicolumn{3}{|c|}{2009} & \multirow[b]{2}{*}{$\mathrm{DiD}$} \\
\hline & Control & Treated & Diff(Before) & Control & Treated & Diff(After) & \\
\hline \multicolumn{8}{|c|}{ Panel A: emp. \& unemp.; inc_selfemp; no covariates } \\
\hline Risk & 3.914 & 4.877 & 0.963 & 3.284 & 4.914 & 1.629 & 0.666 \\
\hline Std. error & 0.029 & 0.148 & 0.151 & 0.030 & 0.139 & 0.142 & 0.207 \\
\hline $\mathrm{t}$ & 132.73 & 10.44 & 6.40 & -17.01 & 9.04 & 5.65 & 3.22 \\
\hline $\mathrm{P}>\mathrm{t}$ & 0.000 & 0.000 & $0.000 * * *$ & 0.000 & 0.000 & $0.000 * * *$ & $0.001 * * *$ \\
\hline $\mathrm{N}$ & 7029 & 324 & & 7029 & 324 & & \\
\hline \multicolumn{8}{|c|}{ Panel B: emp. \& unemp.; selfemp; no covariates } \\
\hline Risk & 3.923 & 4.835 & 0.912 & 3.294 & 5.015 & 1.721 & 0.809 \\
\hline Std. error & 0.029 & 0.165 & 0.168 & 0.030 & 0.159 & 0.162 & 0.233 \\
\hline $\mathrm{t}$ & 133.48 & 9.45 & 5.44 & -17.1 & 9.29 & 5.91 & 3.47 \\
\hline $\mathrm{P}>\mathrm{t}$ & 0.000 & 0.000 & $0.000 * * *$ & 0.000 & 0.000 & $0.000 * * *$ & $0.001^{* * *}$ \\
\hline $\mathrm{N}$ & 7086 & 267 & & 7086 & 267 & & \\
\hline
\end{tabular}

Source: Authors own calculations from Socio-Economic Panel (SOEP), data for years 1984-2010, version 27, SOEP, 2011, doi:10.5684/soep.v27.

Notes: $* * *$ indicate significance at the $1 \%$ level, ** significance at the $5 \%$ level, ${ }^{*}$ significance at the $10 \%$ level. Robust standard errors are reported.

Columns 2 to 4 of table 4 present the pre-treatment risk attitudes for entrepreneurs and nonentrepreneurs, and columns 5 to 7 show the corresponding post-treatment risk attitudes. Column 8 (DiD) depicts the difference between both values, which can be interpreted as the average treatment effect on the treated group. Comparing the average risk values for entrepreneurs and non-entrepreneurs in 2004, we find that entrepreneurs (inc_selfemp) had a higher willingness to take occupational risks than non-entrepreneurs. This difference of 0.96 is highly significant and in line with prior research that argues that more risky individuals are more likely to become entrepreneurs (Barsky et al., 1997; Cramer et al., 2002; Caliendo, Fossen \& Kritikos, 2009, 2010, 2014). With regard to the post-treatment period 2009, we find that this difference increases from 0.96 to 1.63 in the year 2009, implying a large increase in the difference between risk attitudes of individuals entering entrepreneurship and nonentrepreneurs. As column 8 shows, this increase in the difference by 0.67 is large and significant, providing support for the argument that risk attitudes change over time and that entrepreneurship has a positive effect on individual willingness to take occupational risks. The results also hold when we use the proxy selfemp. Here, the DiD estimate even increases by 0.81 points.

Table 5 presents the results for the $\mathrm{DiD}$ approach with the covariates. In line with the regression estimates depicted in table 3 , the set of covariates consists of individual information from the year 2004 and includes variables on gender, origin (East or West 
Germany, German or foreigner), education (using the ISCED classification), age, work experience, unemployment experience, nationality, disability, marital status, income from finance (differentiated by rents and interest), the number of children, height, duration of actual employment, and whether the individual's father was an entrepreneur when the individual was 15 years of age. The results for this specification remain robust. While the coefficients for the $\mathrm{DiD}$ remain almost constant ( 0.71 when using inc_selfemp, 0.83 when using selfemp), the insertion of covariates reduces the pre-treatment differences in the willingness to take occupational risks to 0.67 and 0.69 .

TABLE 5

DiD approach, sample employed and unemployed in 2004

\begin{tabular}{|c|c|c|c|c|c|c|c|}
\hline \multirow[b]{2}{*}{$\begin{array}{l}\text { Outcome } \\
\text { variable }\end{array}$} & \multicolumn{3}{|c|}{2004} & \multicolumn{3}{|c|}{2009} & \multirow[b]{2}{*}{ DiD } \\
\hline & Control & Treated & Diff(Before) & Control & Treated & Diff(After) & \\
\hline \multicolumn{8}{|c|}{ Panel A: emp. \& unemp.; inc_selfemp } \\
\hline Risk & 2.861 & 3.529 & 0.668 & $2 . \overline{22}$ & 3.597 & 1.377 & 0.709 \\
\hline Std. error & 0.648 & 0.668 & 0.149 & 0.648 & 0.661 & 0.144 & 0.206 \\
\hline $\mathrm{T}$ & 4.41 & 3.86 & 4.48 & 1.87 & 3.96 & 5.59 & 3.44 \\
\hline $\mathrm{P}>\mathrm{t}$ & 0.000 & 0.000 & $0.000 * * *$ & 0.001 & 0.000 & $0.000 * * *$ & $0.001 * * *$ \\
\hline $\mathrm{N}$ & 6811 & 308 & & 6811 & 308 & & \\
\hline \multicolumn{8}{|c|}{ Panel B: emp. \& unemp.; selfemp } \\
\hline Risk & 2.842 & 3.534 & 0.692 & 2.202 & 3.727 & 1.525 & 0.833 \\
\hline Std. error & 0.648 & 0.671 & 0.166 & 0.648 & 0.665 & 0.164 & 0.232 \\
\hline $\mathrm{t}$ & 4.39 & 3.87 & 4.16 & 1.85 & 4.15 & 5.78 & 3.59 \\
\hline $\mathrm{P}>\mathrm{t}$ & 0.000 & 0.000 & $0.000 * * *$ & 0.001 & 0.000 & $0.000 * * *$ & $0.000 * * *$ \\
\hline $\mathrm{N}$ & 6865 & 254 & & 6865 & 254 & & \\
\hline
\end{tabular}

Source: Authors own calculations from Socio-Economic Panel (SOEP), data for years 1984-2010, version 27, SOEP, 2011, doi:10.5684/soep.v27.

Notes: emp $=$ employed in 2004, unemp $=$ unemployed in 2004. $* * *$ indicate significance at the $1 \%$ level, $* *$ significance at the $5 \%$ level, * significance at the $10 \%$ level. Robust standard errors are reported. See table 2 for a full list of included covariates. Covariates refer to the year 2004.

The results also remain robust when we check whether entrepreneurs are still entrepreneurs in 2009. That is, we check whether individuals who, for example, became self-employed in 2005 and dropped out one year later harm our results. In this case, we restrict our treatment group to individuals who became self-employed in 2005, 2006, 2007, 2008, or 2009 and were still self-employed in 2009. Table 6 indicates stable results in both specifications, with increasing values of willingness to take occupational risks by 0.93 and 0.89 . Pre-treatment levels of risk differences remain in the range from 0.62 to 0.75 . 
TABLE 6

DiD approach, sample employed and unemployed in 2004, entrepreneurs continuous to 2009

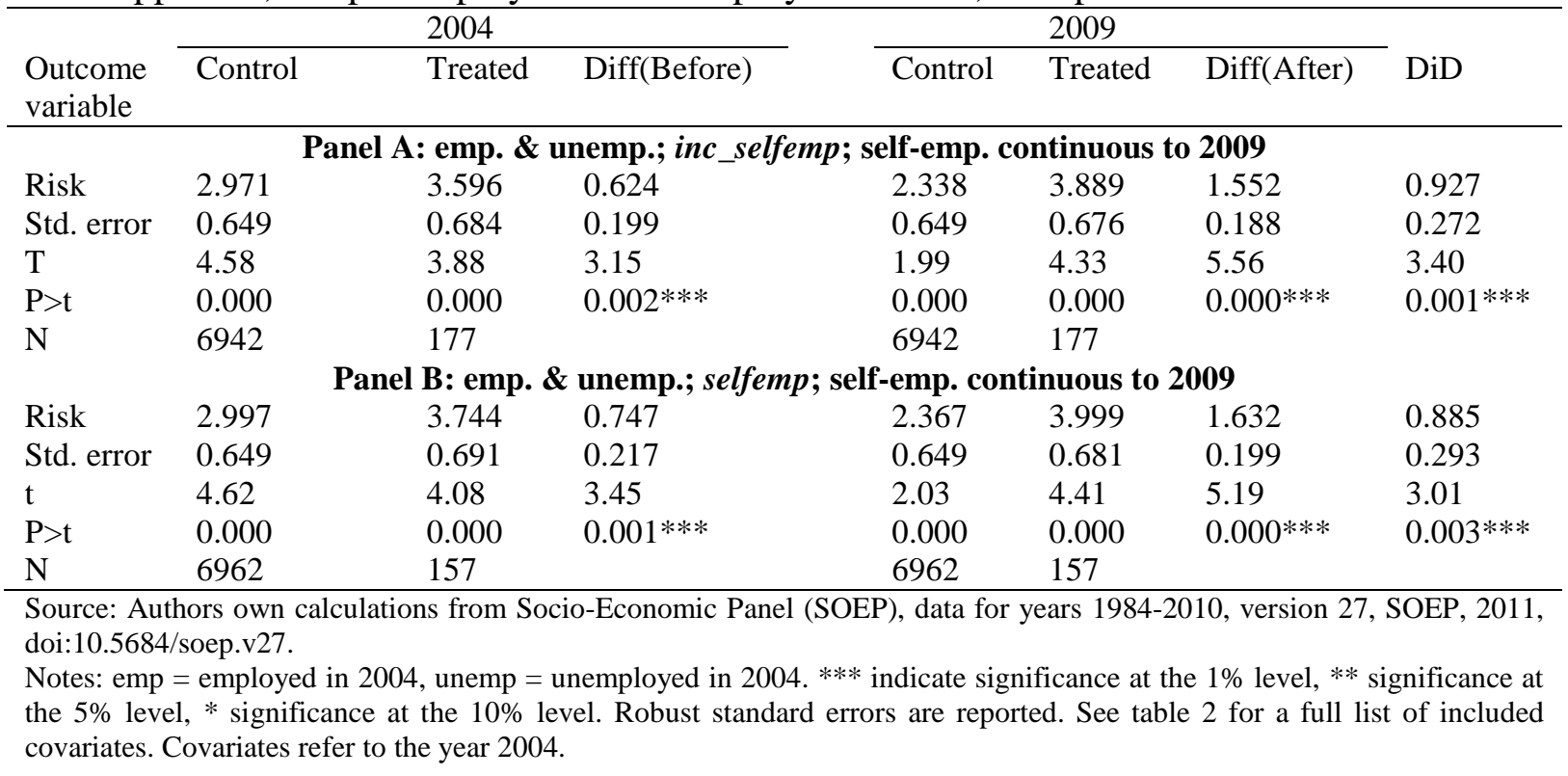

\subsection{Different transition paths}

The data set facilitates distinguishing between different paths of transition to entrepreneurship. Here, we differentiate between nascent entrepreneurs who were employed or unemployed in 2004 and become self-employed later. Thus, we control for whether the former employment status of the entrepreneurs influences changes in the willingness to take occupational risks. Table 7 shows the results. Entrepreneurs with a transition from regular employment experience a significant average increase in their willingness to take occupational risks of between 0.64 and 0.75 points. ${ }^{8}$ Note that in both cases, pre-treatment differences in risk attitudes in 2004 decrease to 0.53 and 0.54. For transitions from unemployment to entrepreneurship we find a substantially larger increase in risk attitudes. The differences hold values of between 1.21 and 1.35 at a 5\% significance level.

\footnotetext{
${ }^{8}$ If not stated otherwise, all regressions include the entire set of control variables (see table 2) with the exception of regressions restricted to the sample of employed individuals, which also controls for the time span individuals are employed at their current employer.
} 
TABLE 7

DiD approach, sub-sample employed and unemployed in 2004

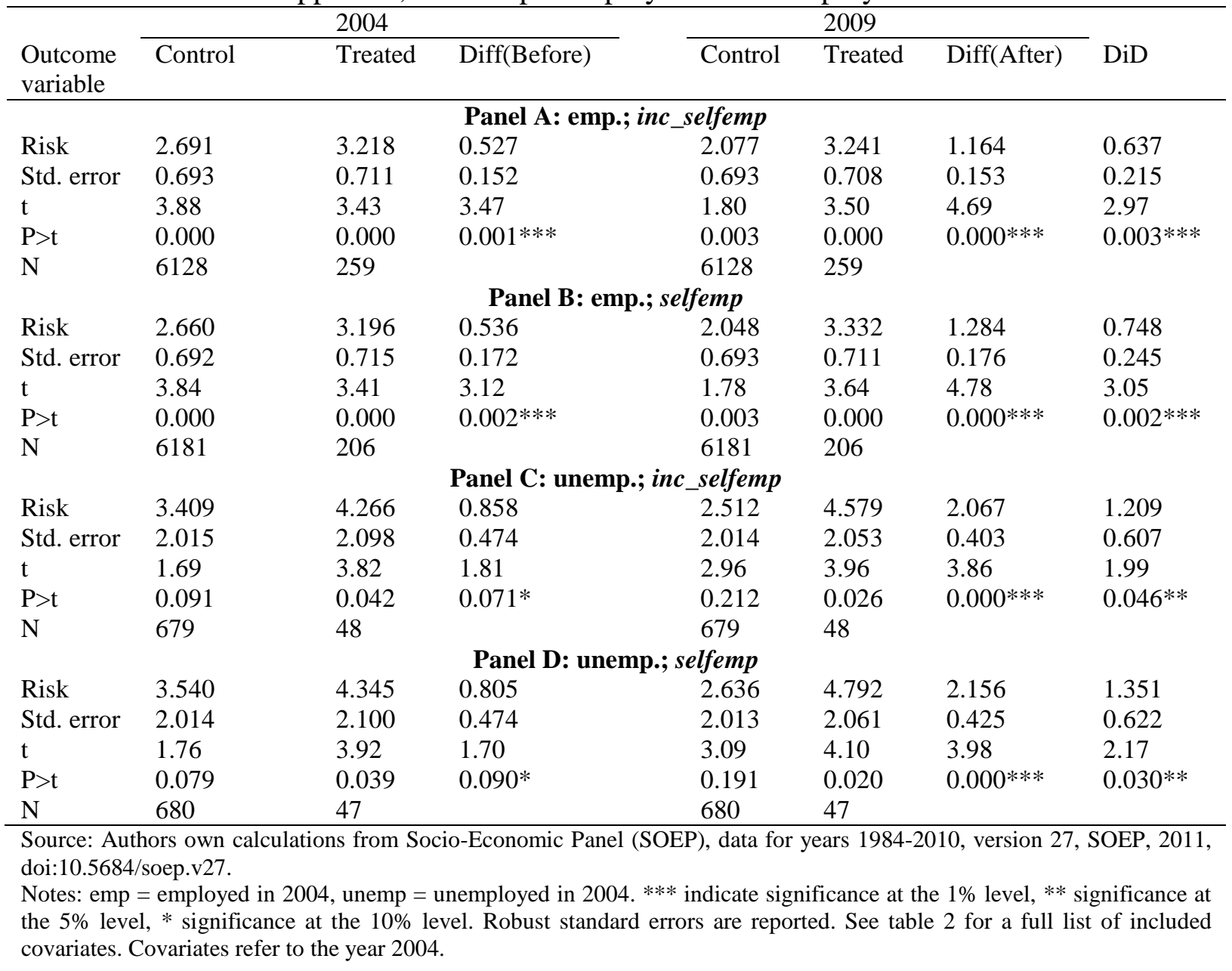

\subsection{Exogeneity of pre-treatment outcome and covariates I}

The DiD design relies on several critical assumptions. Individuals may anticipate becoming an entrepreneur, which entails changes in risk attitudes or pre-treatment adaptation in other covariates. Thus, our risk measure in 2004 could already be an outcome from planning to enter entrepreneurship. We try to ensure that the pre-treatment outcomes as well as covariates are not affected by the decision to become an entrepreneur by making use of a question in the SOEP wave in 2003. Individuals were asked to estimate the probability that career changes would take place within the next two years, on a 100-point scale, where 0 meant that such change would definitely not occur. One part of this question involves the likelihood of becoming self-employed and/or freelancing. In what follows, we restrict the sample to individuals who stated that the likelihood of becoming self-employed was zero. That is, we focus only on those who definitely did not want or expect to become self-employed in the near future. 
The restriction of the sample leads to a decrease in the number of entrepreneurs, who were unemployed in 2004, to 21 cases. Therefore, we report only the results for the full sample and for the transition from regular employment to entrepreneurship. The results, depicted in table 8, also remain robust in this specification. Entrepreneurship leads to increases in the willingness to take occupational risks of between 0.95 and 1.12 points. These changes are highly significant at the $1 \%$ level. Notably, this specification also emphasizes the small and non-significant differences in individual risk attitudes of nascent entrepreneurs and nonentrepreneurs in the pre-treatment period. The differences here range from 0.16 to 0.41 points, casting doubts on the assumption that risk attitudes of nascent entrepreneurs are higher by nature, remain stable over time, and are not affected by entrepreneurship itself.

TABLE 8

DiD approach, full sample and subsample employed in 2004, with no intention to become an entrepreneur in 2003

\begin{tabular}{|c|c|c|c|c|c|c|c|}
\hline \multirow[b]{2}{*}{$\begin{array}{l}\text { Outcome } \\
\text { variable }\end{array}$} & \multicolumn{3}{|c|}{2004} & \multicolumn{3}{|c|}{2009} & \multirow[b]{2}{*}{$\mathrm{DiD}$} \\
\hline & Control & Treated & Diff(Before) & Control & Treated & Diff(After) & \\
\hline \multicolumn{8}{|c|}{ Panel A: emp. \& unemp.; inc_selfemp; no intent becoming self-emp. in 2004} \\
\hline Risk & 3.003 & 3.127 & 0.125 & 2.361 & 3.493 & 1.131 & 1.007 \\
\hline Std. error & 0.654 & 0.689 & 0.211 & 0.654 & 0.681 & 0.201 & 0.290 \\
\hline $\mathrm{t}$ & 4.59 & 3.18 & 0.59 & 2.02 & 3.96 & 5.14 & 3.47 \\
\hline $\mathrm{P}>\mathrm{t}$ & 0.000 & 0.000 & 0.553 & 0.000 & 0.000 & $0.000 * * *$ & $0.001 * * *$ \\
\hline $\mathrm{N}$ & 6811 & 156 & & 6811 & 156 & & \\
\hline \multicolumn{8}{|c|}{ Panel B: emp. \& unemp.; selfemp; no intent becoming self-emp. in 2004} \\
\hline Risk & 3.018 & 3.222 & 0.204 & 2.378 & 3.692 & 1.314 & 1.110 \\
\hline Std. error & 0.653 & 0.692 & 0.230 & 0.653 & 0.683 & 0.221 & 0.318 \\
\hline $\mathrm{t}$ & 4.62 & 3.31 & 0.89 & 2.04 & 4.21 & 5.22 & 3.49 \\
\hline $\mathrm{P}>\mathrm{t}$ & 0.000 & 0.000 & 0.375 & 0.000 & 0.000 & $0.000 * * *$ & $0.000 * * *$ \\
\hline $\mathrm{N}$ & 6865 & 132 & & 6865 & 132 & & \\
\hline \multicolumn{8}{|c|}{ Panel C: emp.; inc_selfemp; no intent becoming self-emp. in 2004} \\
\hline Risk & 2.383 & 2.684 & 0.301 & 1.753 & 3.009 & 1.256 & 0.954 \\
\hline Std. error & 0.853 & 0.885 & 0.226 & 0.853 & 0.887 & 0.244 & 0.331 \\
\hline $\mathrm{t}$ & 2.79 & 2.72 & 1.33 & 1.65 & 3.13 & 4.21 & 2.88 \\
\hline $\mathrm{P}>\mathrm{t}$ & 0.005 & 0.002 & 0.183 & 0.040 & 0.001 & $0.000 * * *$ & $0.004 * * *$ \\
\hline $\mathrm{N}$ & 4425 & 114 & & 4425 & 114 & & \\
\hline \multicolumn{8}{|c|}{ Panel D: emp.; selfemp; no intent becoming self-emp. in 2004} \\
\hline Risk & 2.338 & 2.750 & 0.412 & 1.710 & 3.239 & 1.529 & 1.117 \\
\hline Std. error & 0.853 & 0.890 & 0.254 & 0.853 & 0.889 & 0.270 & 0.370 \\
\hline $\mathrm{t}$ & 2.74 & 2.80 & 1.62 & 1.60 & 3.38 & 4.55 & 3.02 \\
\hline $\mathrm{P}>\mathrm{t}$ & 0.006 & 0.002 & 0.105 & 0.045 & 0 & $0.000^{* * *}$ & $0.003 * * *$ \\
\hline $\mathrm{N}$ & 4447 & 92 & & 4447 & 92 & & \\
\hline $\begin{array}{l}\text { Source: A } \\
\text { doi: } 10.56 \\
\text { Notes: em } \\
\text { the } 5 \% \text { le }\end{array}$ & $\begin{array}{l}\text { s own } \\
\text { ep.v27. }\end{array}$ & from & conomic $\mathrm{P}$ & data & Irs 19 & , ve & DEP, 2011, \\
\hline
\end{tabular}

\subsection{Exogeneity of pre-treatment outcome and covariates II}

In a similar vein, pre-treatment values of risk attitudes and covariates might be less or not affected by the treatment if a sufficient time span exists between pre-treatment and treatment. 
We check for this by focusing only on entrepreneurs who entered into self-employment not before 2007, 2008 or 2009, so that there are at least three years between the responses to the questions on risk attitudes and entry into entrepreneurship. Table 9 reports the results. In all regressions, the coefficients of the post-treatment differences in risk attitudes remain highly significant and quantitatively large. The values range from 0.77 to 1.40 , depending on the empirical specification. Pre-treatment differences in risk attitudes stay between 0.34 and 0.72 .

TABLE 9

DiD approach, full sample with nascent entrepreneurs entering in 2007, 2008, or 2009

\begin{tabular}{|c|c|c|c|c|c|c|c|}
\hline \multirow[b]{2}{*}{$\begin{array}{l}\text { Outcome } \\
\text { variable }\end{array}$} & \multicolumn{3}{|c|}{2004} & \multicolumn{3}{|c|}{2009} & \multirow[b]{2}{*}{ DiD } \\
\hline & Control & Treated & Diff(Before) & Control & Treated & Diff(After) & \\
\hline \multicolumn{8}{|c|}{ Panel A: emp. \& unemp.; inc_selfemp; self-emp. not before 2007} \\
\hline Risk & 2.929 & 3.632 & 0.703 & 2.288 & 3.756 & 1.468 & 0.765 \\
\hline Std. error & 0.655 & 0.685 & 0.190 & 0.655 & 0.680 & 0.192 & 0.269 \\
\hline $\mathrm{T}$ & 4.47 & 3.96 & 3.71 & 1.95 & 4.12 & 4.69 & 2.84 \\
\hline $\mathrm{P}>\mathrm{t}$ & 0.000 & 0.000 & $0.000 * * *$ & 0.000 & 0.000 & $0.000 * * *$ & $0.004 * * *$ \\
\hline $\mathrm{N}$ & 6800 & 170 & & 6800 & 170 & & \\
\hline \multicolumn{8}{|c|}{ Panel B: emp. \& unemp.; inc_selfemp; self-emp. not before 2008} \\
\hline Risk & 3.013 & 3.735 & 0.721 & 2.371 & 3.982 & 1.611 & 0.889 \\
\hline Std. error & 0.658 & 0.712 & 0.259 & 0.658 & 0.704 & 0.252 & 0.360 \\
\hline $\mathrm{T}$ & 4.58 & 4.03 & 2.79 & 2.04 & 4.36 & 4.25 & 2.47 \\
\hline $\mathrm{P}>\mathrm{t}$ & 0.000 & 0.000 & $0.005^{* * *}$ & 0.000 & 0.000 & $0.000 * * *$ & $0.014 * *$ \\
\hline $\mathrm{N}$ & 6797 & 97 & & 6797 & 97 & & \\
\hline \multicolumn{8}{|c|}{ Panel C: emp. \& unemp.; inc_selfemp; self-emp. not before 2009} \\
\hline Risk & 3.060 & 3.400 & 0.340 & 2.417 & 4.010 & 1.593 & 1.253 \\
\hline Std. error & 0.662 & 0.753 & 0.352 & 0.662 & 0.774 & 0.391 & 0.525 \\
\hline $\mathrm{t}$ & 4.63 & 3.51 & 0.97 & 2.09 & 4.38 & 3.55 & 2.39 \\
\hline $\mathrm{P}>\mathrm{t}$ & 0.000 & 0.000 & 0.333 & 0.000 & 0.000 & $0.000 * * *$ & $0.017 * *$ \\
\hline $\mathrm{N}$ & 6793 & 41 & & 6793 & 41 & & \\
\hline \multicolumn{8}{|c|}{ Panel D: emp. \& unemp.; selfemp; self-emp. not before 2007} \\
\hline Risk & 2.873 & 3.583 & 0.710 & 2.232 & 4.057 & 1.825 & 1.115 \\
\hline Std. error & 0.655 & 0.698 & 0.241 & 0.655 & 0.692 & 0.239 & 0.339 \\
\hline $\mathrm{T}$ & 4.39 & 3.89 & 2.95 & 1.89 & 4.55 & 5.38 & 3.29 \\
\hline $\mathrm{P}>\mathrm{t}$ & 0.000 & 0.000 & $0.003^{* * *}$ & 0.001 & 0.000 & $0.000 * * *$ & $0.001 * * *$ \\
\hline $\mathrm{N}$ & 6854 & 116 & & 6854 & 116 & & \\
\hline \multicolumn{8}{|c|}{ Panel E: emp. \& unemp.; selfemp; self-emp. not before 2008} \\
\hline Risk & 2.956 & 3.675 & 0.720 & 2.315 & 4.439 & 2.124 & 1.404 \\
\hline Std. error & 0.658 & 0.755 & 0.371 & 0.658 & 0.743 & 0.357 & 0.514 \\
\hline $\mathrm{T}$ & 4.49 & 3.91 & 1.94 & 1.98 & 4.93 & 4.65 & 2.73 \\
\hline $\mathrm{P}>\mathrm{t}$ & 0.000 & 0.000 & $0.052 *$ & 0.000 & 0.000 & $0.000 * * *$ & $0.006 * * *$ \\
\hline $\mathrm{N}$ & 6839 & 55 & & 6839 & 55 & & \\
\hline
\end{tabular}

Source: Authors own calculations from Socio-Economic Panel (SOEP), data for years 1984-2010, version 27, SOEP, 2011, doi:10.5684/soep.v27.

Notes: emp $=$ employed in 2004, unemp $=$ unemployed in $2004 . * * *$ indicate significance at the $1 \%$ level, ${ }^{* *}$ significance at the $5 \%$ level, * significance at the $10 \%$ level. Robust standard errors are reported. See table 2 for a full list of included covariates. Covariates refer to the year 2004. Results of the panel version emp. \& unemp.; selfemp; self-emp. not before 2009 are omitted because of a low number of cases.

\subsection{Common trend assumption}

The DiD design only offers reliable estimates if both sub-populations (entrepreneurs and nonentrepreneurs) not being treated experience the same time trends in risk attitudes, conditional on the covariates (Lechner, 2011). It is, however, not possible to test this assumption directly. 
We control for the validity of this assumption by comparing the changes in willingness to take occupational risks of non-entrepreneurs between 2004 and 2009 and those that started a new business in the period after 2009. Both groups should experience similar time trends in risk attitudes between 2004 and 2009 because they are not subject to the treatment. We present estimates for different empirical specifications using both proxies for self-employment. First, with the main occupational status definition, we define self-employed as becoming selfemployed in 2010, 2011, or 2012, and aggregates of these years. Second, when using transition to income from self-employment as a proxy, we rely on income information from 2010 and/or 2011 to identify individuals who became entrepreneurs. Table 10 depicts the results for the single years, and table 11 depicts the results for aggregate years.

TABLE 10

DiD approach, full sample with entrepreneurs entering in 2010, 2011, or 2012

\begin{tabular}{|c|c|c|c|c|c|c|c|}
\hline \multirow[b]{2}{*}{$\begin{array}{l}\text { Outcome } \\
\text { variable }\end{array}$} & \multicolumn{3}{|c|}{2004} & \multicolumn{3}{|c|}{2009} & \multirow[b]{2}{*}{ DiD } \\
\hline & Control & Treated & Diff(Before) & Control & Treated & Diff(After) & \\
\hline \multicolumn{8}{|c|}{ Panel A: emp. \& unemp.; inc_selfemp; self-emp. in 2010} \\
\hline Risk & 3.117 & 3.734 & 0.617 & 2.471 & 3.303 & 0.831 & 0.215 \\
\hline Std. error & 0.664 & 0.734 & 0.306 & 0.665 & 0.740 & 0.329 & 0.449 \\
\hline $\mathrm{t}$ & 4.69 & 3.96 & 2.02 & 2.15 & 3.38 & 1.27 & 0.48 \\
\hline $\mathrm{P}>\mathrm{t}$ & 0.000 & 0.000 & $0.044^{* *}$ & 0.000 & 0.000 & $0.012 * *$ & 0.632 \\
\hline $\mathrm{N}$ & 6737 & 51 & & 6737 & 51 & & \\
\hline \multicolumn{8}{|c|}{ Panel B: emp. \& unemp.; inc_selfemp; self-emp. in 2011} \\
\hline Risk & 3.103 & 3.408 & 0.305 & 2.455 & 3.138 & 0.683 & 0.378 \\
\hline Std. error & 0.666 & 0.792 & 0.43 & 0.667 & 0.807 & 0.451 & 0.623 \\
\hline $\mathrm{t}$ & 4.66 & 3.49 & 0.71 & 2.13 & 3.23 & 1.14 & 0.61 \\
\hline $\mathrm{P}>\mathrm{t}$ & 0.000 & 0.000 & 0.478 & 0.000 & 0.000 & 0.130 & 0.544 \\
\hline $\mathrm{N}$ & 6698 & 37 & & 6698 & 37 & & \\
\hline \multicolumn{8}{|c|}{ Panel C: emp. \& unemp.; selfemp; self-emp. in 2011} \\
\hline Risk & 3.028 & 3.323 & 0.295 & 2.383 & 3.094 & 0.711 & 0.416 \\
\hline Std. error & 0.666 & 0.784 & 0.431 & 0.666 & 0.779 & 0.413 & 0.597 \\
\hline $\mathrm{t}$ & 4.55 & 3.40 & 0.68 & 2.06 & 3.21 & 1.30 & 0.70 \\
\hline $\mathrm{P}>\mathrm{t}$ & 0.000 & 0.000 & 0.494 & 0.000 & 0.000 & $0.085 *$ & 0.486 \\
\hline $\mathrm{N}$ & 6724 & 35 & & 6724 & 35 & & \\
\hline \multicolumn{8}{|c|}{ Panel D: emp. \& unemp.; selfemp; self-emp. in 2012} \\
\hline Risk & 3.071 & 3.432 & 0.361 & 2.424 & 3.699 & 1.275 & 0.914 \\
\hline Std. Error & 0.667 & 0.830 & 0.492 & 0.667 & 0.866 & 0.541 & 0.731 \\
\hline $\mathrm{t}$ & 4.60 & 3.51 & 0.73 & 2.10 & 3.84 & 2.05 & 1.25 \\
\hline $\mathrm{P}>\mathrm{t}$ & 0.000 & 0.000 & 0.464 & 0.000 & 0.000 & $0.018 * *$ & 0.211 \\
\hline $\mathrm{N}$ & 6686 & 30 & & 6686 & 30 & & \\
\hline
\end{tabular}

Source: Authors own calculations from Socio-Economic Panel (SOEP), data for years 1984-2012, version 29, SOEP, 2013, doi:10.5684/soep.v29.

Notes: emp $=$ employed in 2004, unemp $=$ unemployed in 2004. $* * *$ indicate significance at the $1 \%$ level, ${ }^{* *}$ significance at the $5 \%$ level, * significance at the $10 \%$ level. Robust standard errors are reported. See table 2 for a full list of included covariates. Covariates refer to the year 2004. Results of the panel version self-employment as main activity in 2010 are omitted because of a low number of cases. Panels A and C apply the SOEP waves 2004 to 2011. Panels B and D apply the SOEP waves 2004 to 2012.

The findings add credibility to the identification assumptions. The single year values of the DiD values are all insignificant and range from 0.22 to 0.38 , when using the transition to income from self-employment in 2010 or 2011. The results are similar for the selfemp proxy. 
Here, we find higher values for the DiD. However, in none of these specifications is the DiD statistically significant. Notably, also pre-treatment differences remain at low range between 0.29 and 0.62

The results of the aggregated year specifications are also strongly in favor of common trends in risk attitudes of non-entrepreneurs and entrepreneurs entering 2010 onwards. The estimated DiD values are all insignificant and range from 0.28 to 0.51 . When considering only individuals with a self-reported probability of entering into entrepreneurship being zero in 2009, pre-treatment differences as well as the DiD values strongly decrease. While panel D still finds a very small positive difference in change of risk attitudes between nonentrepreneurs and entrepreneurs entering after 2009, this value becomes even negative when using selfemp. Furthermore, panels B to D in table 11 report very low and insignificant pretreatment differences between those two groups. 
TABLE 11

DiD approach, full sample with entrepreneurs entering in 2010, 2011, and 2012

\begin{tabular}{|c|c|c|c|c|c|c|c|}
\hline \multirow[b]{2}{*}{$\begin{array}{l}\text { Outcome } \\
\text { variable }\end{array}$} & \multicolumn{3}{|c|}{2004} & \multicolumn{3}{|c|}{2009} & \multirow[b]{2}{*}{ DiD } \\
\hline & Control & Treated & Diff(Before) & Control & Treated & Diff(After) & \\
\hline \multicolumn{8}{|c|}{ Panel A: emp. \& unemp.; inc_selfemp; self-emp. in 2010 \& 2011} \\
\hline Risk & 3.090 & 3.578 & 0.488 & 2.442 & 3.214 & 0.772 & 0.284 \\
\hline Std. error & 0.664 & 0.712 & 0.255 & 0.664 & 0.718 & 0.270 & 0.371 \\
\hline $\mathrm{t}$ & 4.65 & 3.78 & 1.91 & 2.11 & 3.33 & 1.54 & 0.77 \\
\hline $\mathrm{P}>\mathrm{t}$ & 0.000 & 0.000 & $0.056^{*}$ & 0.000 & 0.000 & $0.004^{* * *}$ & 0.443 \\
\hline $\mathrm{N}$ & 6700 & 88 & & 6700 & 88 & & \\
\hline \multicolumn{8}{|c|}{ Panel B: emp. \& unemp.; selfemp; self-emp. in 2010 \& 2011} \\
\hline Risk & 3.088 & 3.417 & 0.329 & 2.442 & 3.106 & 0.664 & 0.335 \\
\hline Std. error & 0.664 & 0.753 & 0.366 & 0.664 & 0.751 & 0.361 & 0.513 \\
\hline $\mathrm{t}$ & 4.65 & 3.52 & 0.90 & 2.11 & 3.22 & 1.26 & 0.65 \\
\hline $\mathrm{P}>\mathrm{t}$ & 0.000 & 0.000 & 0.368 & 0.000 & 0.000 & $0.065 *$ & 0.513 \\
\hline $\mathrm{N}$ & 6743 & 45 & & 6743 & 45 & & \\
\hline \multicolumn{8}{|c|}{ Panel C: emp. \& unemp.; selfemp; self-emp. in 2010 to 2012} \\
\hline Risk & 3.092 & 3.432 & 0.339 & 2.442 & 3.352 & 0.910 & 0.571 \\
\hline Std. error & 0.664 & 0.724 & 0.296 & 0.664 & 0.732 & 0.308 & 0.427 \\
\hline $\mathrm{t}$ & 4.66 & 3.56 & 1.15 & 2.11 & 3.56 & 2.19 & 1.34 \\
\hline $\mathrm{P}>\mathrm{t}$ & 0.000 & 0.000 & 0.251 & 0.000 & 0.000 & $0.003 * * *$ & 0.181 \\
\hline $\mathrm{N}$ & 6713 & 75 & & 6713 & 75 & & \\
\hline
\end{tabular}

Panel D: emp. \& unemp.; inc_selfemp; self-emp. in 2010 \& 2011, no intent becoming self-emp. in 2009

$\begin{array}{llllllll}\text { Risk } & 2.978 & 3.223 & 0.245 & 2.329 & 2.648 & 0.318 & 0.073 \\ \text { Std. Error } & 0.666 & 0.769 & 0.390 & 0.666 & 0.806 & 0.451 & 0.596 \\ \mathrm{t} & 4.47 & 3.30 & 0.63 & 2.00 & 2.67 & 0.41 & 0.12 \\ \mathrm{P}>\mathrm{t} & 0.000 & 0.000 & 0.530 & 0.000 & 0.001 & 0.480 & 0.902 \\ \mathrm{~N} & 6700 & 40 & & 6700 & 40 & & \end{array}$

Panel E: emp. \& unemp.; selfemp; self-emp. in 2010 to 2012, no intent becoming self-emp. in 2009

$\begin{array}{llllllll}\text { Risk } & 3.062 & 3.249 & 0.187 & 2.411 & 2.582 & 0.171 & -0.016 \\ \text { Std. error } & 0.665 & 0.776 & 0.411 & 0.665 & 0.809 & 0.465 & 0.620 \\ \mathrm{t} & 4.61 & 3.30 & 0.45 & 2.08 & 2.58 & 0.15 & -0.03 \\ \mathrm{P}>\mathrm{t} & 0.000 & 0.000 & 0.650 & 0.000 & 0.001 & 0.714 & 0.979 \\ \mathrm{~N} & 6713 & 39 & & 6713 & 39 & & \end{array}$

Source: Authors own calculations from Socio-Economic Panel (SOEP), data for years 1984-2012, version 29, SOEP, 2013, doi:10.5684/soep.v29.

Notes: emp = employed in 2004, unemp = unemployed in 2004. ${ }^{* * *}$ indicate significance at the $1 \%$ level, $* *$ significance at the $5 \%$ level, * significance at the $10 \%$ level. Robust standard errors are reported. See table 2 for a full list of included covariates. Covariates refer to the year 2004. The results of the panel version emp. \& unemp.; selfemp; self-emp. in 2010 to 2011, no intent becoming self-emp. in 2009 are omitted because of a low number of cases. Panel B applies SOEP waves 2004 to 2011. Panels A, C, D, and E and apply SOEP waves 2004 to 2012.

Findings suggest that non-entrepreneurs and "non-entering” entrepreneurs exhibited the same time trend in risk attitudes during the 2004-2009 period: Both groups experience a decrease in risk attitudes. This is in sharp contrast with the regression results for individuals entering entrepreneurship before 2010, in which all regressions show an increase in individual risk preferences for the treatment group.

\section{CONCLUSION AND IMPLICATIONS}

Assumptions of stable preferences are widespread in the economics discipline (Bowles, 1998). For example, studies on risk attitudes and entrepreneurial activity take risk preferences for granted. In this paper, we show that entrepreneurship has a quantitatively large and highly significant feedback effect on individual willingness to take occupational risks. In line with 
other studies, we use self-employment as a proxy for entrepreneurship. As an identification strategy, we make use of risk information on individuals at the time they were either regularly employed or unemployed. We measure risk attitudes at a second point in time when some individuals in the group entered self-employment. Our DiD estimations reveal that individuals who experience a transition to entrepreneurship display a significantly greater willingness to take occupational risks than individuals who remain regularly employed or unemployed in the same period.

The results resist several robustness checks. Our data set enables us to rule out the possibility that individuals had already adjusted their risk attitudes or other control variables before treatment. That is, we ensure that anticipation effects did not harm our results. We also provide evidence in favor of a common trend assumption, which is a key element in the DiD approach. That is, we control for whether entrepreneurs, who started their business after we measured the second time risk preferences, experience the same time trend in risk attitudes as non-entrepreneurs. Furthermore, we rely on two measures of self-employment: the first measure pertains to self-employment as main occupation and the second to receiving income from self-employment. We also check whether changes in the willingness to take occupational risks are influenced by the former employment status of the "future" entrepreneurs. The results remain robust.

Our findings suggest that entry into entrepreneurship leads to endogenous changes in the individual willingness to take risk in occupation. This is in contrast with assumptions on stable preferences. Thus, we need to take into account this preference endogeneity when accurately predicting the likelihood of risk attitudes on entrepreneurship. Furthermore, where preferences are endogenous they will have explanatory power in settings different from their application (Bowles, 1998). In the case of entry into entrepreneurship, this might be related to entrepreneurial survival. Endogenous adaptation in risk attitudes may reflect learning in the business context, thus learned influences on behavior through self-attribution. However, once acquired the preferences are internalized and might become generalized reasons for behavior. Therefore, this work may provide the empirical ground for a more in-depth analysis of the effects of markets and economic institutions on preferences. 


\section{References}

Ahn, Taehyun, “Attitudes toward risk and self-employment of young workers," Labour Economics 17:2 (2010), 434-442.

Amaral, A. Miguel, Rui Baptista, and Fancisco Lima, "Serial Entrepreneurship: Impact of Human Capital on Time to Re-Entry,” Small Business Economics 37:1 (2011), 1-21.

Ashenfelter, Orley, "Estimating the Effect of Training Programs on Earnings," The Review of Economics and Statistics 60:1 (1978), 47-57.

Audretsch, David B., and Michael Fritsch, "The Geography of Firm Births in Germany," Regional Studies 28:4 (1994), 359-365.

Audretsch, David B., Max C. Keilbach, and Erik E. Lehmann, Entrepreneurship and Economic Growth (Oxford: Oxford University Press, 2006).

Barsky, Robert B., Thomas Juster, Miles S. Kimball, and Matthew D. Shapiro, "Preference Parameters and Individual Heterogeneity: An Experimental Approach in the Health and Retirement Study,” Quarterly Journal of Economics 112:2 (1997), 537-579.

Block, Joern, Philipp Sandner, and Frank Spiegel, “How Do Risk Attitudes Differ within the Group of Entrepreneurs? The Role of Motivation and Procedural Utility,” Journal of Small Business Management (forthcoming), DOI: 10.1111/jsbm.12060.

Borghans, Lex, Angela Lee Duckworth, James J. Heckman, and Bas ter Weel, "The Economics and Psychology of Personality Traits,” Journal of Human Resources 43:4 (2008), 972-1059.

Bowles, Samuel, “Endogenous Preferences: The Cultural Consequences of Markets and other Economic Institutions,“ Journal of Economic Literature 36:1 (1998), 75-111.

Brockhaus, Robert H., “Risk Taking Propensity of Entrepreneurs,” Academy of Management Journal 23:3 (2008), 509-520.

Caliendo, Marco, Frank M. Fossen, and Alexander S. Kritikos, "Risk Attitudes of Nascent Entrepreneurs - New Evidence from an Experimentally Validated Survey,” Small Business Economics 32:2 (2009), 153-167. 
Caliendo, Marco, Frank M. Fossen, and Alexander S. Kritikos, “The Impact of Risk Attitudes on Entrepreneurial Survival,” Journal of Economic Behavior \& Organization 76:1 (2010), 45-63.

Caliendo, Marco, Frank M. Fossen, and Alexander S. Kritikos, "Personality Characteristics and the Decision to Become and Stay Self-Employed.” Small Business Economics 42:4 (2014), 787-814.

Card, David and Alan B. Krueger, "Minimum Wages and Employment: A Case Study of the Fast-Food Industry in New Jersey and Pennsylvania," The American Economic Review 84:4 (1994), 772-793.

Cramer, Mars (J.S.), Joop Hartog, Nicole Jonker, and Mirjam Van Praag, "Low Risk Aversion Encourages the Choice for Entrepreneurship: An Empirical Test of a Truism,” Journal of Economic Behavior and Organization 48:1 (2002), 29-36.

Das, T. K. and Bing-Sheng Teng, “Time and Entrepreneurial Risk Behaviour," Entrepreneurship: Theory and Practice 22:2 (1997), 69-71.

Dohmen, T., Armin Falk, David Huffman, and Uwe Sunde, "The Intergenerational Transmission of Risk and Trust Attitudes,” Review of Economic Studies 79:2 (2012), 645-677.

Dohmen, T., Armin Falk, David Huffman, Uwe Sunde, Jürgen Schupp, and Gert G. Wagner, "Individual Risk Attitudes: Measurement, Determinants, and Behavioral Consequences,” Journal of the European Economic Association 9:3 (2011), 522-550.

Fairlie, Robert W., “Drug Dealing and Legitimate Self-Employment, “ Journal of Labor Economics 20:3 (2002), 538-567.

Hartog, Joop, Ada Ferrer-i-Carbonell and Nicole Jonker, "Linking Measured Risk Aversion to Individual Characteristics,” Kyklos 55:1 (2002), 3-26.

Jaeger, David A., Thomas Dohmen, Armin Falk, David Huffman, Uwe Sunde, and Holger Bonin, “Direct Evidence on Risk Attitudes and Migration,” The Review of Economics and Statistics 92:3 (2010), 684-689.

Janney, Jay J., and Gregory G. Dess, “The Risk Concept for Entrepreneurs Reconsidered: New Challenges to the Conventional Wisdom,” Journal of Business Venturing 21:3 (2006), 385-400. 
Lane, Robert, The Market Experience (Cambridge: Cambridge University Press, 1991).

Lechner, Michael, “The Estimation of Causal Effects by Difference-in-Difference Methods,” Foundations and Trends in Econometrics 4:3 (2011), 165-224.

Politis, Diamanto, (2005), “The Process of Entrepreneurial Learning: A Conceptual Framework,” Entrepreneurship Theory \& Practice, 29, 399-424.

Rubin, Donald. B., "Assignment to Treatment Group on the Basis of a Covariate," Journal of Educational Statistics 2:1 (1977), 1-26.

Sarasvathy, Saras D., Anil R. Menon, and Graciela Kuechle, "Failing Firms and Successful Entrepreneurs: Serial Entrepreneurship as a Temporal Portfolio,” Small Business Economics 40:2 (2013), 417-434.

Sarasvathy, Saras D., Herbert A. Simon, and Lester Lave, “Perceiving and Managing Business Risks: Differences between Entrepreneurs and Bankers,” Journal of Economic Behavior and Organization 33:2 (1998), 207-226.

Ucbasaran, Deniz, Mike Wright, and Paul Westhead, “A Longitudinal Study of Habitual Entrepreneurs: Starters and Acquirers,” Entrepreneurship and Regional Development 15:3 (2003), 207-228.

Ucbasaran, Deniz, Mike Wright, and Paul Westhead, “Opportunity Identification and Pursuit: Does an Entrepreneur's Human Capital Matter?” Small Business Economics 30:2 (2008), 153-173.

Van Gelderen, Marco, Lidewey van de Sluis, and Paul Jansen, “Learning Opportunities and Learning Behaviors of Small Business Starters: Relations with Goal Achievement, Skill Development and Satisfaction,” Small Business Economics 25:1 (2005), 97-108.

Wagner, Gert G., Joachim R. Frick, and Jürgen Schupp, “The German Socio-Economic Panel Study (SOEP) - Scope, Evolution and Enhancements,” Schmollers Jahrbuch 127: 1 (2007), 139-169. 
Wagner, Gert G., Richard V. Burkhauser, and Friederike Behringer, “The English Language Public Use File of the German Socio-Economic Panel,” Journal of Human Resources 28:2 (1993), 429-433.

Westhead, Paul and Mike Wright, "Novice, Serial and Portfolio Founders: Are They Different?” Journal of Business Venturing 13:3 (1998), 173-204.

Zhao, Hao and Scott E. Seibert, “The Big-Five Personality Dimensions and Entrepreneurial Status: A Meta-Analysis Review,” Journal of Applied Psychology 91:2 (2006), 259271. 
APPENDIX

Detailed description of the calculation of the variables

\begin{tabular}{|c|c|}
\hline Label & Description \\
\hline Riskocc04 & Willingness to take occupational risks in 2004 (11 point scale) \\
\hline Riskocc09 & Willingness to take occupational risks in 2009 (11 point scale) \\
\hline Riskocc0409 & Change in willingness to take occupational risks from 2004 to 2009 \\
\hline Inc_selfemp & Dummy = 1 if individual received income from self-employment (after 2004) \\
\hline Selfemp & Dummy = 1if individual was self-employment as main activity (after 2004) \\
\hline Sex & Dummy $=1$ if female \\
\hline Age & Age of the individual in 2004 \\
\hline Age_sq & Age squared \\
\hline ISCED & Education level in 2004 based on ISCED classification \\
\hline Work exp. & Years of work experience in 2004 \\
\hline Unemp exp. & Years of unemployment experience in 2004 \\
\hline Duration & Year of current employment relationship in 2004 \\
\hline Married & Dummy = 1 if married or living together in 2004 \\
\hline Kids & Number of children under 17 living in the household in 2004 \\
\hline East & Dummy $=1$ if individual lives in Eastern Germany in 2004 \\
\hline German & Dummy= 1 if individual is from Germany \\
\hline Disable & Dummy $=1$ if individuals is handicapped/physically challenged \\
\hline Inc_Rent & Amount income from rent in 2004 in euro \\
\hline Inc_Interest & Amount income from interest and dividends in 2004 in euro \\
\hline Inc. Finance & Sum of income from rents, interest, and dividends in euro \\
\hline Height & Body height \\
\hline Father_entrepr & $\begin{array}{l}\text { Dummy }=1 \text { if individual's father was an entrepreneur when she/he was } 15 \text { years } \\
\text { of age }\end{array}$ \\
\hline
\end{tabular}

